\title{
Telling New Stories
}

An Encounter with:

Ellen K. Feder. Family Bonds: Genealogies of Race and Gender. Oxford and New York: Oxford University Press, 2007. 145 pages.

\section{Chlö̈ TAYLOR}

In her introductory chapter to Family Bonds: Genealogies of Race and Gender, Ellen K. Feder suggests that "the extraordinary range of Foucault's appeal across the humanities and social sciences is owing to the narrative presentation of his analyses, together with the possibilities his method offers for telling new stories ..." (19). While the philosophical merits of narrative have already been advocated by scholars such as Hilde Lindemann Nelson, Feder cites Ladelle McWhorter in order to explain further why storytelling matters (19-20). As McWhorter writes:

The success of history belongs to those who are capable of seizing these stories, to replace those who had used them, to disguise themselves so as to pervert them, invert their meaning, and redirect them against those who initially told them; controlling this complex mechanism, they will make it function so as to overcome storytellers through their own stories. (60)

Foucault's genealogies show that the truths we currently accept, however inevitable and commonsensical they may seem, are in fact the products of stories-stories that could have been told otherwise. He moreover shows that to change these stories and the power effects that they have we need to not only critique the stories that we are told but to replace them with new narratives. Foucault's own narratives show the contingency of received accounts regarding medicine, madness, sexuality, and punishment, and, equally importantly, replaces these stories 
with new histories that forefront the power struggles that resulted in the present. This ability to tell new stories is essential for convincing ourselves of the possibility of recreating reality otherwise.

Fittingly, then, the strength of Feder's book lies in the stories that its central chapters tell. Chapter Two, "The Family in the Tower: The Triumph of Levittown and the Production of a New Whiteness," tells the tale of Levittowns — a string of racially-segregated suburbs built by the Levitt organization in the decades after World War II. The U.S. Federal Housing Authority and the GI Bill of 1944 provided funding for William Levitt's projects, facilitating suburban living for returning GIs and their families (if they were white), in the process forcing the wives of these GIs out of the workforce and back into traditional gender roles (28). Feder examines the manners in which the families in Levittowns were disciplined by the Levitt organization into norms of both whiteness and gender. Mirroring Bentham's Panopticon, Feder suggests that suburban families were placed in individual and almost identical cells (houses) where they were conscious of being monitored by the firm as well as their neighbours. Worrying, "What will the neighbours think?," these families internalized the rules of the firm and the community and came to selfdiscipline. If they broke rules regulating everything from the mowing of lawns to the use of collapsible racks rather than clotheslines, these families could be fined or ejected from the community. Immigrant families from eastern and southern Europe-but not black familieswere allowed to live in Levittown, and thus came to identify as white by affiliation with the racially exclusive communities in which they lived, but also through the inculcation of norms of whiteness established by the Levitt firm and by the community. Feder examines the manners in which the architectural innovations of Levittown and the equipping of its homes-which were isolated, had no public transportation to the city, and contained individual washers and dryers 
and vacuum cleaners - helped to make housework and childcare a full-time job for the wives of Levittown, many of whom had been subject to the sweeping layoffs of women workers in the years following the end of the war. Changing norms of gender and race were thus deployed by Levitt's firm — and by the state that funded it — and taken on by the inhabitants of Levittown.

Chapter Three, "Boys Will Be Boys: Disciplinary Power and the Production of Gender," tells, amongst other stories, the tale of Nathan, a four-year-old American boy who is diagnosed with Gender Identity Disorder in the 1970s. Interestingly, it is when his "extremely effeminate" behaviour elicits critical comments from other four-year-old children at school—such as "You can't be a little girl" - that his teachers and parents seek psychiatric treatment not only for him, but, as Feder notes, also for his mother. Although Nathan's mother is never diagnosed, she is clearly identified by the doctors as part of the problem. Consequently, she is trained by psychiatrists to mother her child in a normalizing fashion, just as her child is trained to behave according to traditional gender norms. As Feder points out, the fact that this elaborate disciplining of both Nathan and his mother is instigated by the comments of four-year-old children, "a group of individuals who are not generally conceived as powerful," compellingly illustrates Foucault's argument that disciplinary power is everywhere, and comes not "from above" but "from below" (Feder 49-50).

Others stories told in Chapter Three involve gay youth and children diagnosed with intersex conditions, while in Chapter Four, "Of Monkeys and Men: Biopower and the Production of Race," Feder tells a story about the U.S. "Violence Initiative" of 1992. Each of these narratives invaluably illustrates the manners in which disciplinary and regulatory power operate to deploy racialized and gendered identities within and upon families, thus successfully displacing the stories about race, gender and the family that have been authoritatively told by 
medical and other "experts," while also focusing from a Foucauldian perspective on an institution — the family — which Feder argues is underexplored in Foucault's own work. While these stories are intriguing and convincing, much weaker and indeed baffling are the theoretical generalizations that Feder tries to draw from them-generalizations which are belied consistently by the stories themselves.

Feder suggests in Chapter One and again in Chapter Five that the reason that feminists such as Betty Friedan and Nancy Chodorow have frequently theorized gender while remaining blind to race is that gender and race result from different kinds of power and thus function in different manners. Because race and gender are the effects of different forms of power, Feder argues, they are difficult to think simultaneously. A section of Chapter Five is titled, "Gender and Race: Now You See It, Now You Don't," and includes an image of a reversible figureground drawing, used by Gestalt psychologists, to illustrate this manner in which race and gender supposedly cannot be thought simultaneously (90). Just as when looking at this image one first sees a vase and then two faces (or, alternately, first sees two faces and then a vase), unable to have both images in mind at once, so Feder argues that our minds shift back and forth between "seeing" race and "seeing" gender, unable to think the two together. This inability to keep race in mind in discussions of gender is a resulting phenomenon that Feder thinks can be explained by Foucault's accounts of power.

Gender, Feder suggests, is deployed through disciplinary power, which explains why feminists have so successfully taken up Foucault's writings on discipline in order to theorize the process of gendering. Race, on the other hand, is deployed through regulatory power or biopower, which is why the few times that Foucault mentions race it is in the context of his 
discussions of biopower. Race, Feder suggests, cannot be explained through the model of disciplinary power:

Nor, it appears, can an ascription of "disciplinary power" genuinely explain the great disparities in wealth and resources evident when comparing the status of white and nonwhite communities. The multiplicity of measures denying black women reproductive freedom relative to white women are similarly difficult to characterize in these terms, as is the disproportionate number of black men involved in the criminal justice system. Although it is compelling to describe the production of gender as a function of disciplinary power, then, we cannot simply extend that analysis to the production of race. (4-5)

Additionally, Feder argues, gender and race are difficult to think together since one is deployed within the family, while the other is deployed upon it. The family is itself a disciplinary institution, Feder argues, and thus gendering and disciplinary power operate within the family or as an internal form of power. Race-operating through biopower and thus the state-is something that is enforced on families or is an external form of power:

I argue that disciplinary power-and the production of gender with which it is associated-may be located within the family, the privileged location of the internalization of social norms. By contrast, biopower-what Foucault sometimes characterizes as a "regulatory" power that he explicitly associates with the production of race-issues from outside and acts upon the family (5).

Feder is effectively putting race and gender, and disciplinary and regulatory power, in separate boxes, and her thesis can hence be neatly illustrated as follows:

\begin{tabular}{|l|l|}
\hline Gender & Race \\
\hline Disciplinary Power & Regulatory Power (Biopower) \\
\hline Internal to the Family & External to the Family \\
\hline
\end{tabular}


Unfortunately—or perhaps fortunately_Feder's own examples suggest that things are not so tidy. For instance, the case of Levittown showed families being disciplined from the outside, for instance by the Levitt organization and by neighbours. The discussion of Nathan (the little boy diagnosed with Gender Identity Disorder) also shows that discipline is not something that occurs exclusively or even primarily within the family, but that the family itself is disciplined from outside (indeed, the title of an earlier, article version of this chapter is "Disciplining the Family," suggesting that the family is being disciplined and is not the agent of discipline). Nathan is disciplined by his schoolmates, by his teachers, by counselors and psychiatrists - as is his mother. Nathan's mother eventually comes to discipline her son into his "appropriate" gender, but only when she is herself disciplined to do so by external authorities. The same could be said about the parents of children with intersex conditions, who conform to the interventions of doctors because they are themselves disciplined to do so. The worry, "What will the neighbours think?," which Feder invokes to aptly illustrate the way that the neighbourhood is a panoptic environment, also shows the manner in which neighbours discipline families through surveillance (one never knows when they may be watching/listening, but they could be at any time). This once more illustrates the ways that discipline is working upon and not only within the family. Gender in particular is not something that is deployed primarily within the family, but is enforced by many institutions outside the family-institutions that work upon and in collaboration with the family, such as the school and the clinic.

In her introduction to Family Bonds, Feder tells the story of a friend whose parents, having left Brooklyn behind for the suburbs, were appalled by neighbours who treated their front yard as an urban "stoop" by setting up lawn chairs in the front rather than the back yard. Feder ostensibly uses this story to illustrate "the requirements a middle-class 'whiteness' entailed and 
that her parents vigorously assumed, requirements she had unconsciously embraced, informing her own aspirations and judgments" (x). This example of the "stoop thing," and Feder's own analysis of it, demonstrates - contra Feder - the ways that race, ethnicity and class are deployed within the family and in a disciplinary manner. This example of race being deployed within the family once more disturbs Feder's boxes, or the claim that race is biopolitical rather than disciplinary and works on rather than in the family. Race and class, in this example, are internalized by the child as she accepts her parents' values, coming to identify herself not only as a girl but as white and middle-class in the process.

Given the repeated tension between her own examples and her thesis, one wishes that Feder would explain why her stories of racialized phenomena are supposedly "difficult to characterize" in disciplinary terms, and why the disciplinary model cannot be extended to explain the production of race. Even in the instances that Feder herself raises, she frequently needs to qualify the individuals affected by the situations she describes according to their gender as well as their race and mentions the two in a single breath. So for instance she speaks of black women whose reproductive freedom is denied, and of black men who are disproportionately involved in the criminal justice system, of Mama Crips and Welfare Queens and not Papa Crips and Welfare Kings, and the differential treatment of white versus black premarital maternity. Clearly these examples show that race is in fact difficult to think apart from gender, since, as intersection theorists have shown, one must qualify race with gender in each of these and many other cases for them to make sense or hold true. In these examples one does not first think of those disproportionately incarcerated bodies as black, and only later as male, but thinks of them as simultaneously black and male, which is a very different from thinking a gender-neutral blackness and then an unraced maleness in temporal suspension, since what it means to be black 
differs for men and women in contemporary U.S. society, and what it means to be male differs for black men and white men in this same context. Hence, contra Feder, far from needing to think race and gender separately, one cannot think race and gender separately, since each already can only be thought when qualified by the other.

To remain for a moment with Feder's case of the racialization of "justice" (or, more to the point, of racialized injustice) in the U.S., it can be pointed out that the criminal justice system of which Feder writes is gendered as well as racialized: men tend to be incarcerated in prisons for acts that will more likely land women in psychiatric care, but this is more true of white women than black women: black women are more likely to end up in prison than white women who commit the same crimes, and white women are more likely to be psychiatrized (45). If the prison is one of the sites where Feder sees racialization happening, we might also ask how she can deny that race is deployed through disciplinary power when the prison is Foucault's example par excellence of a disciplinary institution. If the prison racializes, discipline and not just biopower must be involved in the deployment of race.

In case this weren't enough, one might mess up Feder's boxes further by discussing the manners in which parents become biopolitical agents (as Foucault himself suggests in Abnormal) and the ways in which biopower deploys gender and not only race-or, a gender that is always already raced. We could, for instance, take the example of state-funded breastfeeding advocacy campaigns as an example of biopower which, without a doubt, enforces gender upon the family. In so doing, however, we must remain cognizant of the ways that this biopolitical gendering is always already racialized and classed: as Rebecca Kukla has shown in her study of breastfeeding advocacy campaigns, the imagery circulated of the nursing mother unfailingly depicts her as white, young, conventionally pretty and normally shaped, and breastfeeding leisurely in a 
domestic environment that suggests that she belongs to a privileged socio-economic class (166). White middle-class women, then, are particularly targeted by these biopolitical campaigns to remain in traditional gendered roles as primary caretakers - the state, or biopower, thus deploys (racialized) gender, just as the family deploys (gendered) race.

There is in fact no reason to infer, as Feder does, from the failure of numerous feminists to include race in their analyses of gender that race and gender cannot be thought together, or only with "difficulty," since, once the problem was pointed out, other feminists (including Feder herself), have provided us with sophisticated analyses of race and gender, and class and sexual orientation for that matter, thought about simultaneously and as inextricably intertwined. When feminists such as bell hooks criticized earlier feminists such as Betty Friedan for neglecting to make race and class explicit in their analyses, they attributed this failing, quite reasonably, to the whiteness and socioeconomic class of the feminists they targeted. They suggested that middle class white feminists tended to mistake the experiences of white middle class women for the experiences of Woman per se because their racial and class privilege permitted them to do so, much as men such as Foucault were able to theorize power relations without making gender explicit in their analyses. Just as we do not need to look further than Foucault's own privileged gender to explain why he was "gender blind," I see no reason why we need to look beyond Chodorow's and Friedan's socio-economic and racial privilege in order to explain-but not accept - why they were blind to issues of class and race in their writings. Once sensitized, however, the difficult thing is not to think these categories together, but to try to see them apart. It is thus difficult to understand why Feder would try so hard to separate again into simplistic boxes intertwinings and co-substantiations of which feminists have worked hard to illuminate the complexities, particularly when her own narratives so consistently undermine this very effort. 
Finally, we might also note that the desire that motivates the thesis of Family Bonds is decidedly un-Foucauldian. Foucault frequently noted that different forms of power are only analytically distinct but are characterized by "overlappings, interactions, and echoes" (History of Sexuality 149). The family in particular is described in The History of Sexuality as a site of interaction between two different forms of power-juridico-discursive power and biopower. If these quite opposed forms of power can overlap within the family, it is all the more likely that regulatory power and disciplinary power could do so, since these are in fact but two levels of a single form of power, or two ways in which power is exercised over life. Disciplinary power is in fact biopower as it targets individual bodies, while regulatory power is biopower as it manages populations; since individual bodies make up populations, and populations consist of individual bodies, it goes without saying that regulatory power and disciplinary power would not only collaborate but, at some point, become indistinct, and that Feder's attempt to separate disciplinary power and regulatory power as producing separate forms of oppressions that work upon the family in very different ways would collapse in just as decidedly a manner as the attempt to compartmentalize race and gender.

\section{Works Cited}

Davis, Angela. Are Prisons Obsolete? New York: Seven Story Press, 2003.

Feder, Ellen K. Family Bonds: Genealogies of Race and Gender. Oxford and New York: Oxford University Press, 2007.

Foucault, Michel. The History of Sexuality: An Introduction. New York: Random House, 1978 (1976).

McWhorter, Ladelle. Bodies and Pleasures: Foucault and the Politics of Sexual Normalization. Bloomington: Indiana University Press, 1999. 
Kukla, Rebecca. "Ethics and Ideology in Breastfeeding Advocacy Campaigns." Hypatia: A Journal of Feminist Philosophy 21, no. 1 (Winter 2006): 157-180. 